University for Business and Technology in Kosovo

UBT Knowledge Center

UBT International Conference

2017 UBT International Conference

Oct 28th, 11:00 AM - 12:30 PM

\title{
The presence of aflatoxin M1 on processed milk in the Republic of Kosovo
}

\author{
Ismail Ferati \\ University for Business and Technology, ismajl.ferati@ubt-uni.net \\ Bizena Bijo \\ Agricultural University of Tirana \\ Durim Alija \\ University of Tetova \\ Eljesa Ziberi \\ University of Tetova
}

Follow this and additional works at: https://knowledgecenter.ubt-uni.net/conference

Part of the Food Science Commons

\section{Recommended Citation}

Ferati, Ismail; Bijo, Bizena; Alija, Durim; and Ziberi, Eljesa, "The presence of aflatoxin M1 on processed milk in the Republic of Kosovo" (2017). UBT International Conference. 172.

https://knowledgecenter.ubt-uni.net/conference/2017/all-events/172

This Event is brought to you for free and open access by the Publication and Journals at UBT Knowledge Center. It has been accepted for inclusion in UBT International Conference by an authorized administrator of UBT Knowledge Center. For more information, please contact knowledge.center@ubt-uni.net. 


\title{
The presence of aflatoxin $M_{1}$ on processed milk in the Republic of Kosovo
}

\author{
Ismail Ferati ${ }^{1}$ Bizena Bijo $^{3}$ Durim Alija ${ }^{2}$, Eljesa Ziberi ${ }^{2}$ \\ ${ }^{1}$ Faculty of Food Science and Biotechnology, University of Business and \\ Technology, Pristina, Kosovo \\ ${ }^{2}$ Faculty of food technology and Nutrition, University of Tetova, , Tetovo, Macedonia \\ ${ }^{3}$ Faculty of Veterinary medicine, Agricultural University of Tirana, Albania \\ ismajl.ferati@ubt-uni.net
}

\begin{abstract}
Aflatoxins are mycotoxins of major concern to the dairy industry. Given the fact that aflatoxins $\mathrm{M}_{1}$ mycotoxins can cause toxic effects called mycotoxicosis. It has been reported that mycotoxins are carcinogenic, tumorigenic, and dermatological in a large number of organisms and cause hepatic carcinoma in humans. This study aims to identify the quantity of mycotoxins $\mathrm{M}_{1}$ in dairy products used by consumers in the Republic of Kosovo. According to the results obtained from the analyzes of processed milk samples we have come to the conclusion that the content of aflatoxin $\mathrm{M}_{1}$ in all types of dairy products is not allowed limits according to the regulation in force for the safety of food products.
\end{abstract}

Keywords: Mycotoxins, Aflatoxins $\mathrm{M}_{1}$, Carcinogenic, Tumorigenic

\section{INTRODUCTION}

A very large number of molds produce toxic substances designated mycotoxins. Some are mutagenic and carcinogenic, some display specific organ toxicity, and some are toxic by other mechanisms. Mycotoxins are produced as secondary metabolites. The primary metabolites of fungi as well as for other organisms are those compounds that are essential for growth. Secondary metabolites are formed during the end of the exponential growth phase and have no apparent significance to the producing organism relative to growth or metabolism. In general, it appears that they are formed when large pools of primary metabolic precursors such as amino acids, acetate, pyruvate, and so on, accumulate. The synthesis of mycotoxins represents one way the fungus has of reducing the pool of metabolic precursors that it no longer requires for metabolism. ${ }^{1}$

Aflatoxins are clearly the most widely studied of all mycotoxins. Knowledge of their existence dates from 1960, when more than 100,000 turkey poults died in England after eating peanut meal imported from Africa and South America. From the poisonous feed were isolated Aspergillus flavus, and a toxin produced by this organism that was designated aflatoxin (Aspergillus flavus toxin-A-fla-toxin). Studies on the nature of the toxic substances revealed the following four components:

It was later determined that A parasiticus produces aflatoxins. Another Aspergillus species, A. nominus, also produces aflatoxins ${ }^{2}$ these compounds are highly substituted coumarins, and at least 18 closely related toxins are known. Aflatoxin $\mathrm{B}_{1}$ (AFB1) is produced by all aflatoxinpositive strains, and it is the most potent of all. AFM1 is a hydroxylated product of AFB1 and appears in milk, urine, and feces as a metabolic product. ${ }^{3} \mathrm{AFL}, \mathrm{AFLH}_{1}, \mathrm{AFQ}_{1}$, and $\mathrm{AFP}{ }_{1}$ are all derived fromAFB ${ }_{1} . \mathrm{AFB}_{1}$ is the 2, 3-dehydro form $\mathrm{OfAFB}_{1}$, and $\mathrm{AFG}_{1}$ is the 2, 3-dihydro form ofAF11. The toxicity of the six most potent aflatoxins decreases in the following order: B1 > 
$\mathrm{M} 1>\mathrm{G} 1>\mathrm{B} 2>\mathrm{M} 2 \neq \mathrm{G} 2 .{ }^{4}$ When viewed under ultraviolet (UV) light, six of the toxins fluoresce as noted:

$\mathrm{B}_{1}$ and $\mathrm{B}_{2}$ - blue; $\mathrm{G}_{1}$ - green; $\mathrm{G}_{2}$-green-blue; $\mathrm{M}_{1}$-blue-violet; $\mathrm{M}_{2}$-violet

No aflatoxins were produced by 25 isolates of A. flavus/parasiticus on wort agar at $2^{\circ}, 7^{\circ}, 41^{\circ}$, or $46^{\circ} \mathrm{C}$ within 8 days, and none was produced under $7.5^{\circ}$ or over $40^{\circ} \mathrm{C}$ even under otherwise favorable conditions ${ }^{5}$. In another study employing Sabouraud's agar, maximal growth of A. flavus and $A$, parasiticus occurred at $330 \mathrm{C}$ when $\mathrm{pH}$ was 5.0 and water activity (aw) was $0.99^{6} \mathrm{At} 15^{\circ} \mathrm{C}$, growth occurred at aw 0.95 but not at 0.90 , while at $27^{\circ}$ and $33^{\circ} \mathrm{C}$, slight growth was observed at an aw of 0.85 . The optimum temperature for toxin production has been found by many to be between $24^{\circ}$ and $28^{\circ} \mathrm{C}$. In one study, maximal growth of $A$. parasiticus was $35^{\circ} \mathrm{C}$, but the highest level of toxin was produced at $25^{\circ} \mathrm{C}^{7}$ The limiting moisture content for $\mathrm{AFB} 1$ and $\mathrm{AFB} 2$ on corn was $17.5 \%$ at a temperature of $24^{\circ} \mathrm{C}$ or higher, with up to $50 \mathrm{ng} / \mathrm{g}$ being produced. ${ }^{8}$ No toxin was produced at $13^{\circ} \mathrm{C}$. Overall, toxin production has been observed over the aw range of 0.93 to 0.98 , with limiting values variously reported as being 0.71 to 0.94 .9 In another study, no detectable quantities of AFB1 were formed by A. parasiticus at aw values of 0.83 and $10{ }^{\circ} \mathrm{C} .10$ The optimum temperature at aw 0.94 was $24^{\circ} \mathrm{C}$ (Figure 1). Growth without demonstrable toxin appeared possible at aw 0.83 on malt agar-containing sucrose. It has been observed by several investigators that rice supports the production of high levels of aflatoxins at favorable temperatures but none is produced at $5{ }^{\circ} \mathrm{C}$ on either rice or cheddar cheese. 11

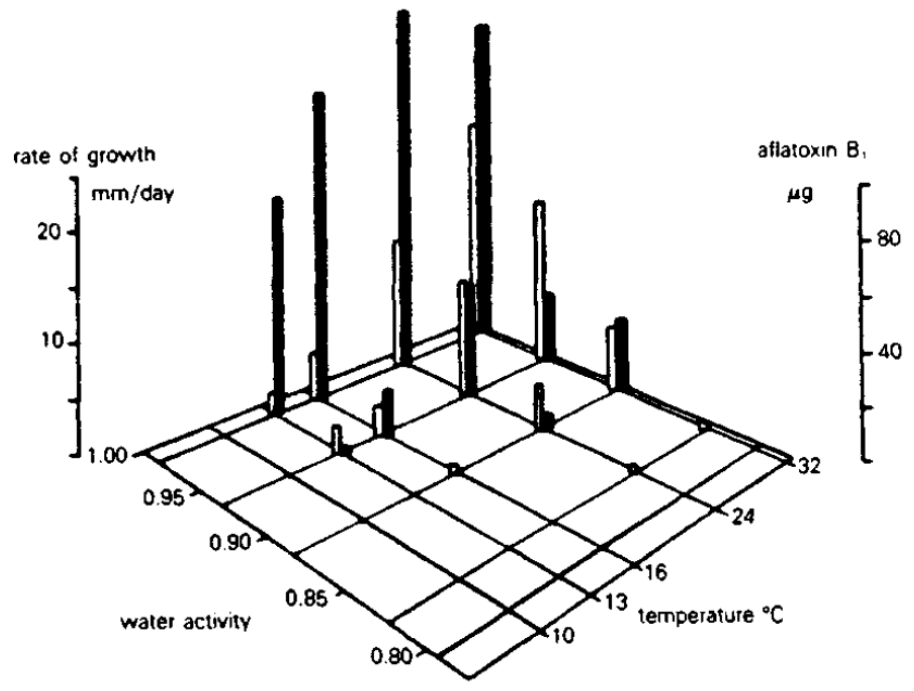

Figure 1 Growth and aflatoxin $\mathrm{B}_{1}$ production on malt extract-glycerine agar at various water activity values and temperatures. White columns: rate of growth; black columns: average AFB 1 production. Source: From Northolt et al., ${ }^{10}$ copyright (C) 1976 by International Association of Milk, Food and Environmental Sanitarians.

Overall, the minimal and maximal parameters that control growth and toxin production by these eukaryotic organisms are not easy to define, in part because of their diverse habitats in nature and in part because of their eukaryotic status. It seems clear that growth can occur without toxin production.

$\mathrm{AFG} 1$ is produced at lower growth temperatures than $\mathrm{AFB} 1$, and while some investigators have found more $\mathrm{AFB} 1$ than $\mathrm{AFG} 1$ at around $30^{\circ} \mathrm{C}$, others have found equal production. With regard to A. fla vus and A. parasiticus, the former generally produces only AFB and AFG. ${ }^{12}$ Aeration 
favors aflatoxin production, and amounts of $2 \mathrm{mg} / \mathrm{g}$ can be produced on natural substrates such as rice, corn, soybeans, and the like. ${ }^{11} \mathrm{Up}$ to 200 to $300 \mathrm{mg} / \mathrm{L}$ can be produced in broth containing appropriate levels of $\mathrm{Zn}^{2+}$. The release ofAFB 1 by A. flavus appears to involve an energy dependent transport system.

Aflatoxins are a group of structurally related mycotoxin which consist of four naturally occurring compounds including aflatoxin $\mathrm{B}_{1}, \mathrm{~B}_{2}, \mathrm{G}_{1}$ and $\mathrm{G}_{2}$ which are mainly produced by three species of moulds namely Aspergillus flavus, A. parasiticus and rarely A. nomius. ${ }^{13}$

Aflatoxin $\mathrm{B}_{1}\left(\mathrm{AFB}_{1}\right)$ has strong teratogenic, mutagenic, and carcinogenic effects. ${ }^{14}$ Aflatoxin $\mathrm{M}_{1}\left(\mathrm{AFM} \mathrm{M}_{1}\right)$ is a monohydroxylated derivate of $\mathrm{AFB}_{1}$, which in liver is metabolized by cytochrome $P 450$ Figure 2. It is excreted into the milk of both human and lactating animals. ${ }^{15} \mathrm{~A}$ direct relationship has been shown between the amount of $\mathrm{AFB}_{1}$ consumption and the secreted $\mathrm{AFM}_{1}$ in milk. It has been shown that in 0.3-6.2\% consumed $\mathrm{AFB}_{1}$ by animals is secreted into milk. ${ }^{16}$ The content of AFM 1 in milk is not significantly affected by thermal process, pasteurization and ultra-high-temperature (UHT) treatment, or storage of dairy products. ${ }^{17}$ Although $\mathrm{AFM}_{1}$ is less carcinogenic and mutagenic than $\mathrm{AFB}_{1}$ as its parental compound, ${ }^{18}$ but the international agency for research on cancer (IARC, 2002) ${ }^{19}$ has re-categorized it from group 2 to group 1 according to recent investigations on its carcinogenicity.

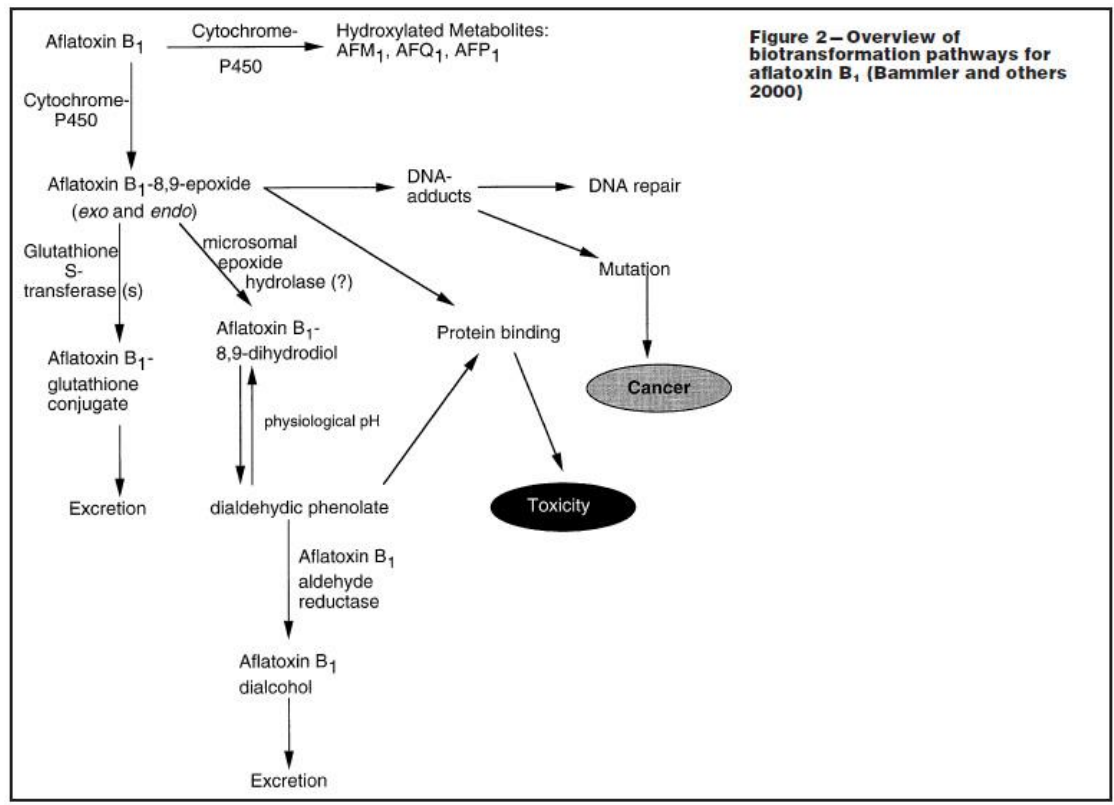

Milk and dairy products constitute an important part of people's diet providing as a good source of calcium and proteins. Therefore, presence of aflatoxins in these products poses an important hygienic risk in human health. Considering its public health significance, many countries have set maximum limits for aflatoxins, which vary among countries. European Community (EC) has prescribed the maximum acceptable level of AFM1 in liquid milk as $50 \mathrm{ng} / \mathrm{l}$ (EC, 2001). Both, US food and drug administration (FDA, 1996) ${ }^{20}$ and institute of standards and industrial research of Iran (ISIRI, 2005) ${ }^{21}$ have set the maximum level of $500 \mathrm{ng} / \mathrm{l}$ of AFM1 in liquid milk. This study was aimed to determine the levels of AFM1 in pasteurized and UHT milk marketed in WestAzerbaijan province as a main dairy producing region in Iran. 


\section{MATERIALS AND METHODS}

For the identification of mycotoxins $\mathrm{M}_{1}$ in UHT milk, the fluorometric method with automated VICAM Series 4 Fluorimeter system was used. A total of 30 samples were analyzed for each different milk percentage $(3.2 \%, 3.5 \%, 3.8 \%)$ analyzed by 10 samples. The analyzes were carried out in the accredited Laboratory of the Food and Veterinary Agency, Pristina. Figures 3 and 4 show schematic sampling procedures and the automatic setup for identifying $\mathrm{M}_{1}$ mycotoxins.

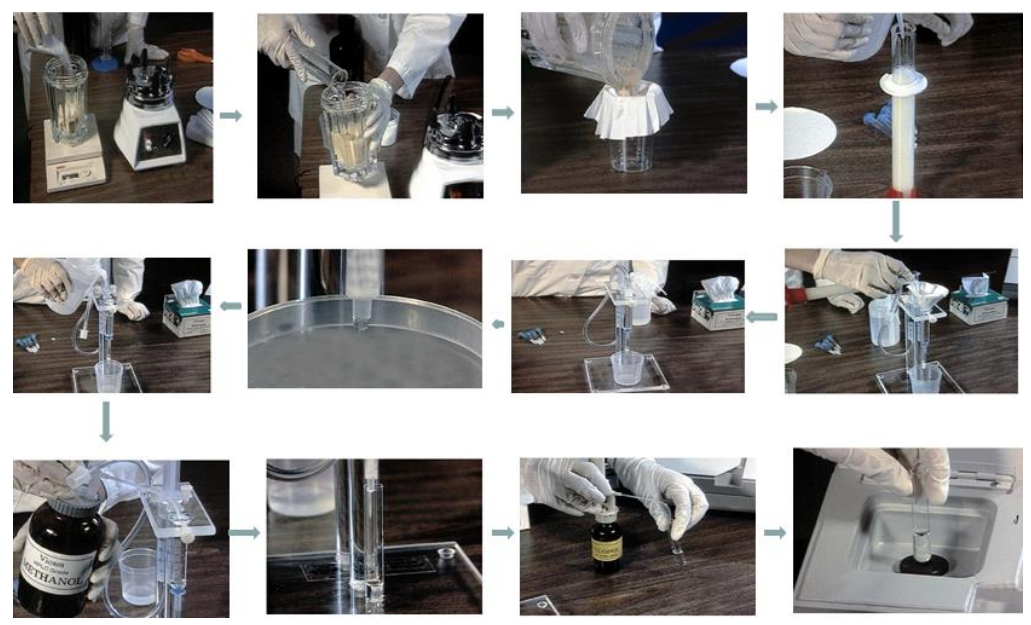

Figure 3. Procedures to be followed for sample preparation for the VICAM automatic system

\section{VICAM.}

Cultivating Success through Sciences

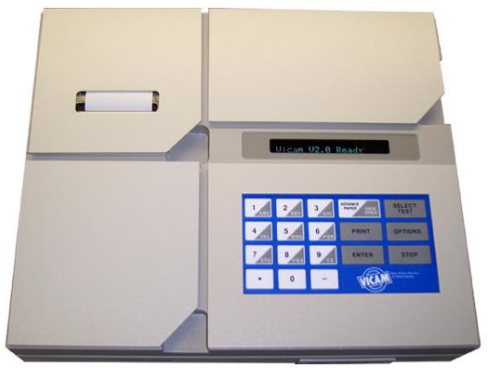

Series 4 Fluorometer Field Service Manual

Figure 4. Automatic system VICAM 


\section{RESULTS E DISCUSSION}

The results obtained in this study are shown in graphs 5, 6 and 7 where they are analyzed by 10 samples for each milk with different fat percentages. The analyzes are carried out every month starting from January to September.

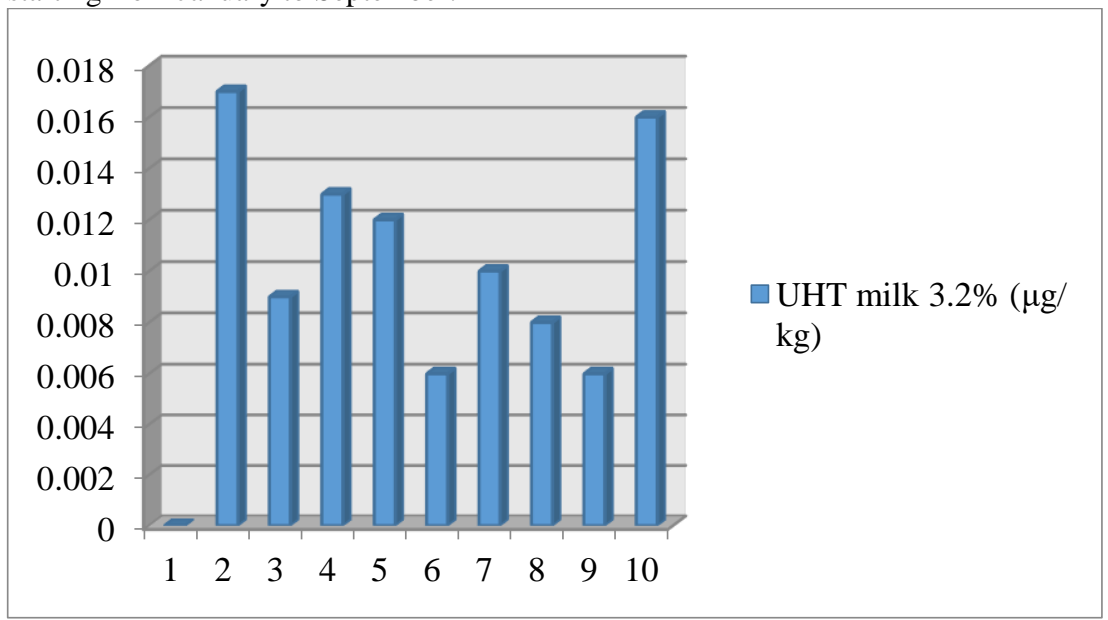

Graph 5.

The results reflected in graph 5 show a smaller amount of mycotoxin $\mathrm{M}_{1}$ in January, while the largest amount in February and September.

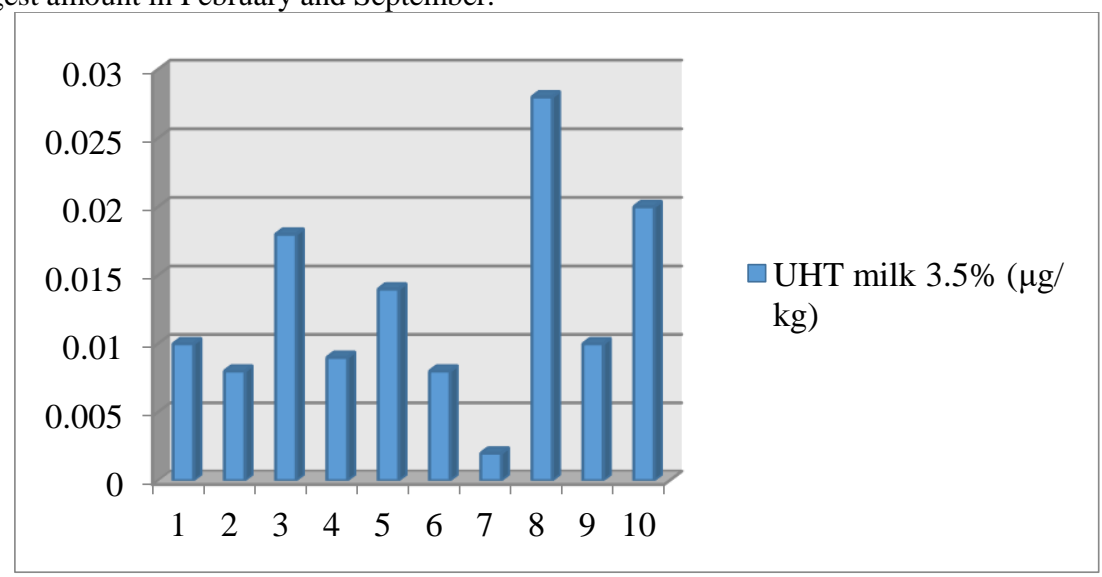

Graph 6.

In the graph no. 6 is the lowest amount of mycotoxin $M_{1}$ in July, and the highest amount in August. 


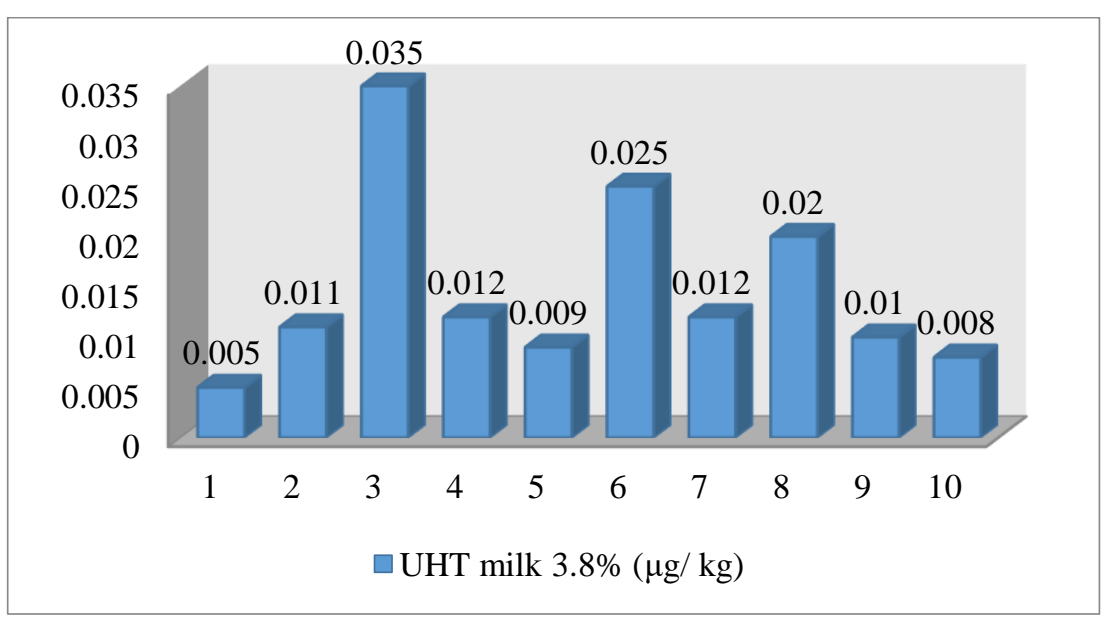

\section{Graph 7}

In the graph no. 7 where the results of mycotoxin $\mathrm{M}_{1}$ are reported is the lowest amount of mycotoxin $\mathrm{M}_{1}$ in January, while the highest amount in March.

The average values of mycotoxins $\mathrm{M}_{1}$ for milk with different percentages are these:

1. Milk with $3.2 \%$ fat $0,010 \mu \mathrm{g} / \mathrm{kg}$,

2. Milk with $3.5 \%$ fat $0.012 \mu \mathrm{g} / \mathrm{kg}$ and

3. Milk with $3.8 \%$ fat $0.009 \mu \mathrm{g} / \mathrm{kg}$.

\section{CONCLUSION}

Based on the results obtained during this study we can conclude:

Milk taken in the study for the period of time meets the safety standards since all the samples taken in the study are below the critical limit set in the regulation $0,05 \mu \mathrm{g} / \mathrm{kg}$, There is an increase in the amount of mycotoxins $\mathrm{M}_{1}$ after the month of February, Control of animal foods to prevent the consumption of aflatoxin $\mathrm{B}_{1}$ and the prevention of mycotoxins $\mathrm{M}_{1}$ in milk.

Regular control of fresh milk for the presence of aflatoxins $\mathrm{M}_{1}$.

\section{REFERENCES}

1. Stark, A.A. 1980. Mutagenicity and carcinogenicity of mycotoxins: DNA binding as a possible mode of action. Annu. Rev. Microbiol. 34:235-262.

2. Kurtzman, CP, B.W Horn, and CW. Hesseltine. 1987. Aspergillus nominus, a new aflatoxin-producing species related to Aspergillus flavus and Aspergillus tamarii. Antonie van Leeuwenhoek 53:147-158.

3. Enomoto, M., and M. Saito. 1972. Carcinogens produced by fungi. Annu. Rev. Microbiol. 26:279-312.

4. Ayres, J.C., J.O. Mundt, and W.E. Sandine. 1980. Microbiology of foods, 658-683. San Francisco: Freeman. 
5. Schindler, A.E 1977. Temperature limits for production of aflatoxin by twenty-five isolates of Aspergillus flavus and Aspergillus parasiticus. J. Food. Protect. 40:39-40.

6. Holmquist, G.U., H.W. Walker, and H.M. Stahr. 1983. Influence of temperature, pH, water activity and antifungal agents on growth of Aspergillus flavus and A. parasiticus. J. Food Sci. $48: 778-782$.

7. Shih, C.N., and E.H. Marth. 1974. Some cultural conditions that control biosynthesis of lipid and aflatoxin by Aspergillus parasiticus. Appl. Microbiol. 27: 452-456.

8. Trenk, H.L., and PA. Hartman. 1970. Effects of moisture content and temperature on aflatoxin production in corn. Appl. Microbiol. 19:781-784.

9. Marth, E.H., and B.G. Calanog. 1976. Toxigenic fungi. In Food microbiology: Public health and spoilage aspects, ed. M.P deFigueiredo and D.F. Splittstoesser, 210-256. Westport, CT: AVI.

10. Northolt, M.D., C.A.H. Verhulsdonk, PS.S. Soentoro, et al. 1976. Effect of water activity and temperature on aflatoxin production by Aspergi.

11. Park, K.Y., and L.B. Bullerman. 1983. Effect of cycling temperatures on aflatoxin production by Aspergillus parasiticus and Aspergillus flavus in rice and cheddar cheese. J. Food ScL 48:889-896.

12. Davis, N.D., and U.L. Diener. 1987. Mycotoxins. In Food and beverage mycology, 2d ed., ed. L.R. Beuchat, 517-570. New York: Van Nostrand Reinhold.

13. Eslami M., Mashak Z., Heshmati A., Shokrzadeh M., Mozaffari Nejad A.S. (2015

14. Barikbin B., Allahresani A., Khosravi R., Khodadadi M. (2015). Detection of aflatoxin M1 in dairy products marked in Iran. Health Scope. 4: e18925.

15. Kamkar A. (2005). A study on the occurrence of aflatoxin M1 in raw milk produced in Sarab city of Iran. Food Control. 16: 593599

16. Ayar A., Sert D., Con A.H. (2007). A study on the occurrence of aflatoxin in raw milk due to feeds. Journal of Food Safety. 27: 199-207.

17. International Agency for Research on Cancer (IARC). (2002). Monograph on the evaluation of carcinogenic risk to humans, world health organization. Some traditional herbal medicines, some mycotoxins, naphthalene and styrene. Summary of data reported and evaluation. 82: 171-175.

18. Food and drug administration (FDA) (1996). Whole milk, low fat milk, skim milkaflatoxin M1 (CPG 7106.210). FDA compliance policy guides. Washington DC

19. Institute of Standards and Industrial Research of Iran (ISIRI). (2005). Milk and milk products-raw milk-specifications and test methods. National Standard No. 164. URL: http: //www.isiri.org/portal/files/std/164.doc. Accessed 6 March 2015. 